\title{
Association equilibria of divalent ions on the surface of liposomes formed from phosphatidylcholine
}

\author{
Izabela Dobrzyńska ${ }^{a}$ \\ Institute of Chemistry, University of Białystok, Ciołkowskiego 1K, 15-245 Białystok, Poland
}

Received 6 June 2018 and Received in final form 26 September 2018

Published online: 10 January 2019

(c) The Author(s) 2019. This article is published with open access at Springerlink.com

\begin{abstract}
Divalent ions, in particular calcium ions, constitute important macroelements in living organisms. They are also found in cell membranes, i.e., ensuring their stabilization or participating in synaptic transmission of nerve impulses. The aim of this work is to describe the interactions of divalent ions, such as $\mathrm{Ca}^{2+}, \mathrm{Ba}^{2+}$, and $\mathrm{Sr}^{2+}$, in electrolytes with the functional groups on the surface of liposomes formed from phosphatidylcholine (PC). Microelectrophoresis is used to determine the surface charge density as a function of $p \mathrm{H}$. The interactions between ions found in solution and the functional groups of PC are described with the use of a seven-equilibrium mathematical model. Using this model along with experimental data on the charge density of the membrane surface, the association constants characterizing this equilibrium are determined. These parameters are used to calculate the theoretical model curves. The validity of the proposed model is confirmed by comparing the theoretically calculated changes in charge density on the liposome surface with the experimental results.
\end{abstract}

\section{Introduction}

Every cell of a living organism is enclosed by an integral cell membrane that protects the cell interior from the external environment. The cell membrane regulates the passage of materials into and out of the cell and, more importantly, communicates with other cells via surface receptors. The lipid bilayer constitutes an essential structural element of a biological membrane with numerous compounds characterized by specific functions [1].

The main phospholipid that forms eukaryotic membranes is phosphatidylcholine (PC), which accounts for about $40-60 \%$ of the total phospholipid content [2]. The electric charge of the cell membrane is a basic property that ensures membrane stability and function. In aqueous solutions of inorganic ions, ion adsorption to the membrane significantly affects the structural and functional properties of the cell. The exposure of lipid membranes to ions in solution affects the electric properties of the membrane due to interactions between the charged groups of the lipid molecules and the surrounding ions. In addition, equilibria at the membrane surface can be changed by adsorption processes, leading to variations in the membrane surface charge density [3-8].

The structure of natural membranes is complex; however, the functions of the membrane can be easily explained by using a membrane model. Liposomes are simplified structures that can be used to model the properties

\footnotetext{
a e-mail: izadob@uwb.edu.pl
}

and functions of natural membranes. The omnipresence of monovalent and bivalent ions in biological systems requires the implementation of analysis describing the impact that these ions exert on the functioning of individual ions in a living organism. Interactions between ions and membranes characterize many of the physicochemical properties of cell membranes $[9,10]$.

Previous studies have described the adsorption of monovalent ions to the surface of the PC layer $[6-8,11]$. The aim of this work is to describe the interactions of divalent ions, such as $\mathrm{Ca}^{2+}, \mathrm{Ba}^{2+}$, and $\mathrm{Sr}^{2+}$, in electrolytes with the functional groups on the surface of liposomes formed from PC. To this end, the effects of monovalent negative ions should be taken into account, which also form complexes with functional groups and affect the electric charge on the membrane surface.

Calcium and magnesium are among the many elements in living organisms. These are important macronutrients in cell physiology. In particular, the flow of $\mathrm{Ca}^{2+}$ ions into and out of the cytoplasm constitutes a signal for many cellular processes $[10,12]$. In addition, the regulated exocytosis of neurotransmitters and neuropeptides is triggered by the depolarization evoked by calcium entry [12]. Although this process is reasonably specific for calcium, several divalent cations with similar physicochemical properties, such as $\mathrm{Ba}^{2+}$ and $\mathrm{Sr}^{2+}$, evoke a transmitter release as well [13]. For example, barium interacts with potassium, causing an increase in the active transport of potassium into the cell and blocking the passive diffusion from cells, 
leading to hypokalemia. This scenario results in a disturbance of the depolarized synaptic membranes and leads to cardiovascular disorders and platelet depolarization in the myocardium, among other conditions [14-18].

The results of this study will be used to explain the diverse phenomena that occur at the lipid membrane in living cells (e.g., transport mechanisms). Interactions between ions and the membrane change a wide spectrum of physicochemical and electrical properties of the membranes. The obtained results will quantitatively describe the physicochemical properties of biological membranes. Solving even the smallest problems affecting biological membranes will enrich our knowledge on their properties and functioning.

\section{Experimental}

\section{Materials}

L- $\alpha$ PC from egg yolk (99\%) was purchased from SigmaAldrich. Chloroform was of chromatographic standard grade (Sigma-Aldrich). Inorganic compounds (calcium chloride, strontium chloride, and barium chloride) were of analytical grade and purchased from $\mathrm{POCH}$ (Gliwice, Poland). The electrolyte solutions $(1 \mathrm{mM} \mathrm{CaCl} 2,1 \mathrm{mM}$ $\mathrm{SrCl}_{2}$, and $1 \mathrm{mM} \mathrm{BaCl}$ ) were prepared from water purified using a Milli-Q system (18.2, Millipore, USA).

\section{Preparation of the phospholipid vesicles}

Liposome dispersions were prepared by sonication of neutral PC, which is used to obtain the small unilamellar liposome vesicle. Dry PC were weighed, dissolved in chloroform $(10 \mathrm{mg} / \mathrm{ml})$. The solvent was evaporated under a gentle stream of argon to obtain dry lipid film. Then, the film was hydrated with $1 \mathrm{mM} \mathrm{MeCl} 2\left(\mathrm{CaCl}_{2}, \mathrm{SrCl}_{2}, \mathrm{BaCl}_{2}\right)$. Liposomes were formed by sonicating the suspension using an ultrasound generator UD 20 (Techpan, Poland). Sonication was applied five times for $1.5 \mathrm{~min}$ each time. Since during the process heat is liberated, cooling the suspension is necessary. It was carried out by using an ice bath (container with a mixture of ice and dry sodium chloride) [7]. The size of the PC liposomes was measured using a Zetasizer Nano ZS device (Malvern Instruments, UK). This apparatus uses a process called Dynamic Light Scattering (DLS) (table 1).

Table 1. Diameter of liposomes formed in solutions containing $\mathrm{Ca}^{2+}, \mathrm{Sr}^{2+}$ or $\mathrm{Ba}^{2+}$ ions.

\begin{tabular}{|c|c|c|c|}
\hline & $d_{\mathrm{Ca}^{2+}}(\mathrm{nm})$ & $d_{\mathrm{Sr}^{2+}}(\mathrm{nm})$ & $d_{\mathrm{Ba}^{2+}}(\mathrm{nm})$ \\
\hline$p \mathrm{H}=3$ & $56.7 \pm 5.9$ & $53.8 \pm 5.4$ & $52.6 \pm 5.2$ \\
\hline$p \mathrm{H}=7$ & $62.4 \pm 6.0$ & $58.8 \pm 5.0$ & $55.5 \pm 4.9$ \\
\hline$p \mathrm{H}=11$ & $65.4 \pm 5.1$ & $60.7 \pm 6.1$ & $56.0 \pm 4.1$ \\
\hline
\end{tabular}

\section{Microelectrophoretic mobility measurements}

The electrophoretic mobility of the phospholipid vesicles in the suspension was determined using laser Doppler velocimetry and a Zetasizer Nano ZS (Malvern Instruments, UK). The measurements were conducted as a function of $p \mathrm{H}$. Each result constitutes the mean of six measurements at a particular $p \mathrm{H}$ value. The liposomes were suspended in $\mathrm{MeCl}_{2}\left(\mathrm{CaCl}_{2}, \mathrm{SrCl}_{2}\right.$, or $\left.\mathrm{BaCl}_{2}\right)$ solution and titrated to the desired $p \mathrm{H}$ with the use of $\mathrm{HCl}$ or $\mathrm{Me}(\mathrm{OH})_{2}$ $\left(\mathrm{Ca}(\mathrm{OH})_{2}, \mathrm{Sr}(\mathrm{OH})_{2}\right.$, or $\left.\mathrm{Ba}(\mathrm{OH})_{2}\right)$. Afterwards, the solutions were placed in the measuring vessel one by one, and then the electrophoretic mobility was determined. All experiments were conducted at least three times at $25^{\circ} \mathrm{C}$.

\section{Theory}

The surface charge density, which is calculated from the determined electrophoretic mobility, is the parameter that characterizes the liposomal surface. Considering the movement of large particles in an electric field, compared to the thickness of a fuzzy layer, it is possible to think of a particle with its double layer as a parallel capacitor whose plates are spaced apart by the thickness of the double layer. The boards have a charge $\delta$ per unit area. After reaching the steady state, in which the particle moves at a constant velocity through the liquid, the frictional and electric forces are equal. Based on the definitions of viscosity, velocity, and mobility, we obtain [19]:

$$
\delta=\frac{\eta \cdot u}{d}
$$

where $u$ is the electrophoretic mobility, $\eta$ the viscosity of the solution, $d$ the diffuse layer thickness.

The diffuse layer thickness was determined from the formula $d=\sqrt{\frac{\varepsilon \cdot \varepsilon_{0} \cdot R \cdot T}{2 \cdot F^{2} \cdot I}}$, where $R$ is the gas constant, $T$ the temperature, $F$ the Faraday number, $I$ the ionic strength of $1 \mathrm{mM} \mathrm{MeCl}_{2}\left(\mathrm{CaCl}_{2}, \mathrm{SrCl}_{2}\right.$ or $\left.\mathrm{BaCl}_{2}\right)$.

Based on the determined mobility of the PC liposomal membrane, the surface charge density $(\delta)$ can be calculated by eq. (1). On the water solution side, the groups $-\mathrm{PO}^{(-)}$and $-\mathrm{N}^{(+)}\left(\mathrm{CH}_{3}\right)_{3}$ are present on the liposome surface formed from $\mathrm{PC}$.

The surface charge density of the lipid membrane results from equilibria existing between the groups localized at the membrane surface and solution ions. Assuming that the $\mathrm{Me}^{2+}\left(\mathrm{Ca}^{2+}, \mathrm{Sr}^{2+}\right.$, or $\left.\mathrm{Ba}^{2+}\right), \mathrm{H}^{+}, \mathrm{OH}^{-}$, and $\mathrm{Cl}^{-}$ions are adsorbed at the $\mathrm{PC}$ surface, the adsorption equilibria can be presented as follows:

$$
\begin{aligned}
\mathrm{B}^{+}+\mathrm{OH}^{-} & \leftrightarrows \mathrm{BOH}, \\
\mathrm{B}^{+}+\mathrm{Cl}^{-} & \leftrightarrows \mathrm{BCl} \\
\mathrm{A}^{-}+\mathrm{H}^{+} & \leftrightarrows \mathrm{AH} \\
\mathrm{A}^{-}+\mathrm{Me}^{2+} & \leftrightarrows \mathrm{AMe}^{+} \\
\mathrm{A}^{-}+\mathrm{AMe}^{+} & \leftrightarrows \mathrm{A}_{2} \mathrm{Me} \\
\mathrm{AMe}^{+}+\mathrm{OH}^{-} & \leftrightarrows \mathrm{AMeOH} \\
\mathrm{AMe}^{+}+\mathrm{Cl}^{-} & \leftrightarrows \mathrm{AMeCl}
\end{aligned}
$$


where $\mathrm{A}^{-}$is the group $-\mathrm{PO}^{(-)}, \mathrm{B}^{+}$is the group $-\mathrm{N}^{(+)}\left(\mathrm{CH}_{3}\right)_{3}$.

The association constants are expressed in the following manner:

$$
\begin{aligned}
K_{1} & =\frac{a_{\mathrm{BOH}}}{a_{\mathrm{B}^{+}} \cdot a_{\mathrm{OH}^{-}}}, \\
K_{2} & =\frac{a_{\mathrm{BCl}}}{a_{\mathrm{B}^{+}} \cdot a_{\mathrm{Cl}^{-}}}, \\
K_{3} & =\frac{a_{\mathrm{AH}}}{a_{\mathrm{A}^{-}} \cdot a_{\mathrm{H}^{+}}}, \\
K_{4} & =\frac{a_{\mathrm{AMe}}}{a_{\mathrm{A}^{-}} \cdot a_{\mathrm{Me}^{2+}}}, \\
K_{5} & =\frac{a_{\mathrm{A}_{2} \mathrm{Me}}}{a_{\mathrm{A}^{-}} \cdot a_{\mathrm{Me}^{2+}}}, \\
K_{6} & =\frac{a_{\mathrm{AMeOH}}}{a_{\mathrm{AMe}} \cdot a_{\mathrm{OH}^{-}}}, \\
K_{7} & =\frac{a_{\mathrm{AMeCl}}}{a_{\mathrm{AMe}^{+}} \cdot a_{\mathrm{Cl}^{-}}},
\end{aligned}
$$

where $K_{1}, \quad K_{2}, \quad K_{3}, \quad K_{4}, \quad K_{5}, K_{6}, \quad K_{7}$ are the association constants $\left(\mathrm{mol} / \mathrm{m}^{2}\right)$ of the groups $-\mathrm{N}^{(+)}\left(\mathrm{CH}_{3}\right)_{3} \mathrm{OH}^{(-)}, \quad-\mathrm{N}^{(+)}\left(\mathrm{CH}_{3}\right)_{3} \mathrm{Cl}^{(-)}, \quad-\mathrm{PO}^{(-)} \mathrm{H}^{(+)}$, $-\mathrm{PO}^{(-)} \mathrm{Me}^{(2+)},\left(-\mathrm{PO}^{(-)}\right){ }_{2} \mathrm{Me}^{(2+)},-\mathrm{PO}^{(-)} \mathrm{Me}^{(2+)} \mathrm{OH}^{(-)}$, $-\mathrm{PO}^{(-)} \mathrm{Me}^{(2+)} \mathrm{Cl}^{(-)}$, respectively.

$a_{\mathrm{A}^{-}}, a_{\mathrm{AH}}, a_{\mathrm{AMe}^{+}}, a_{\mathrm{A}_{2} \mathrm{Me}}, a_{\mathrm{AMeOH}}, a_{\mathrm{AMeCl}}, a_{\mathrm{B}^{+}}, a_{\mathrm{BOH}}$, $a_{\mathrm{AMeCl}}$ are the surface concentrations of the membrane components, $a_{\mathrm{H}^{+}}, a_{\mathrm{Me}^{2+}}, a_{\mathrm{OH}^{-}}, a_{\mathrm{Cl}^{-}}$are the volume concentrations of solution ions.

The concentration balances are expressed as follows:

$$
\begin{aligned}
& a_{\mathrm{B}^{+}}+a_{\mathrm{BOH}}+a_{\mathrm{BCl}}=S, \\
& a_{\mathrm{A}^{-}}+a_{\mathrm{AH}}+a_{\mathrm{AMe}^{+}}+2 a_{\mathrm{A}_{2} \mathrm{Me}}+a_{\mathrm{AMeOH}}+a_{\mathrm{AMeCl}}=S .
\end{aligned}
$$

The surface charge density of the phosphatidylcholine membrane is described by the equation

$$
\delta=\left(a_{\mathrm{B}^{+}}-a_{\mathrm{A}^{-}}+a_{\mathrm{AMe}^{+}}\right) \cdot F,
$$

where $S$ is the total surface concentration of PC, $\delta\left(\frac{\mathrm{C}}{\mathrm{m}^{2}}\right)$ is the surface charge density, $F=96487\left(\frac{\mathrm{C}}{\mathrm{mol}}\right)$ is the Faraday constant.

By eliminating from eqs. (16)-(18) concentrations $a_{\mathrm{AH}}, a_{\mathrm{AMe}^{+}}, a_{\mathrm{A}_{2} \mathrm{Me}}, a_{\mathrm{AMeOH}}, a_{\mathrm{AMeCl}}, a_{\mathrm{BOH}}, a_{\mathrm{AMeCl}}$ using eqs. (9)-(15) the following equations are obtained:

$$
\begin{aligned}
& a_{\mathrm{B}^{+}}\left(1+K_{1} \cdot a_{\mathrm{OH}^{-}}+K_{2} \cdot a_{\mathrm{Cl}^{-}}\right)=S \\
& 2 K_{4} K_{5} \cdot a_{\mathrm{Me}^{2+}} \cdot a_{\mathrm{A}^{-}}^{2}+a_{\mathrm{A}^{-}}\left(1+K_{3} \cdot a_{\mathrm{H}^{+}}+K_{4} \cdot a_{\mathrm{Me}^{2+}}\right. \\
& \left.+K_{4} K_{6} \cdot a_{\mathrm{Me}^{2+}} \cdot a_{\mathrm{OH}^{-}}+K_{4} K_{7} \cdot a_{\mathrm{Me}^{2+}} \cdot a_{\mathrm{Cl}^{-}}\right)=S,(20) \\
& \frac{\delta}{F}=a_{\mathrm{B}^{+}}-a_{\mathrm{A}^{-}}\left(1-K_{4} \cdot a_{\mathrm{Me}^{2+}}\right) .
\end{aligned}
$$

By eliminating from eq. (20) $a_{\mathrm{A}^{-}}$, using eq. (21), the following equation is obtained in the form of a polynomial that can be used to calculate association constants $\left(K_{4}, K_{5}, K_{6}, K_{7}\right)$ :

$$
y=m_{1} x_{1}+m_{2} x_{2}+m_{3} x_{3}+m_{4} x_{4}+m_{5} x_{5}+m_{6} x_{6}+b,
$$

where

$$
\begin{aligned}
y & =\left(K_{4} \cdot a_{\mathrm{H}^{+}}-\frac{2 S}{a_{\mathrm{B}^{+}}-\delta \cdot F^{-1}}\right) \cdot a_{\mathrm{OH}^{-}}^{-1} \\
m_{1} & =\frac{1}{K_{4}}, \\
x_{1} & =\left(1+K_{3} \cdot a_{\mathrm{H}^{+}}-\frac{S}{a_{\mathrm{B}^{+}}-\delta \cdot F^{-1}}\right) \cdot \frac{1}{a_{\mathrm{Me}^{2+}} \cdot a_{\mathrm{OH}^{-}}}, \\
m_{2} & =K_{5}, \\
x_{2} & =\frac{2\left(a_{\mathrm{B}^{+}}-\delta \cdot F^{-1}\right)}{a_{\mathrm{OH}^{-}}} \\
m_{3} & =K_{4}, \\
x_{3} & =\left(1+\frac{S}{a_{\mathrm{B}^{+}}-\delta \cdot F^{-1}}\right) \cdot a_{\mathrm{Me}^{2+}} \cdot a_{\mathrm{OH}^{-}}^{-1}, \\
m_{4} & =K_{4} \cdot K_{6}, \\
x_{4} & =a_{\mathrm{Me}^{2+}} \\
m_{5} & =K_{7} \\
x_{5} & =a_{\mathrm{Cl}^{-}} \cdot a_{\mathrm{OH}^{-}}^{-1}, \\
m_{6} & =K_{4} \cdot K_{7}, \\
x_{6} & =a_{\mathrm{Me}^{2+}} \cdot a_{\mathrm{Cl}^{-}} \cdot a_{\mathrm{OH}^{-}}^{-1} \\
b & =K_{6} \cdot
\end{aligned}
$$

The solution may have the following reactions between the ligand $\mathrm{OH}^{-}$and the $\mathrm{Me}^{2+}\left(\mathrm{Ca}^{2+}, \mathrm{Sr}^{2+}\right.$, or $\left.\mathrm{Ba}^{2+}\right)$ ion:

$$
\begin{aligned}
\mathrm{Me}^{2+}+\mathrm{OH}^{-} & \leftrightarrows \mathrm{MeOH}^{+}, \\
\mathrm{MeOH}^{+}+\mathrm{OH}^{-} & \leftrightarrows \mathrm{Me}(\mathrm{OH})_{2}
\end{aligned}
$$

At such low concentrations of $\mathrm{Me}^{2+}$ ion $(1 \mathrm{mM})$, the reactions described in eq. (24) can be omitted. $\mathrm{Me}(\mathrm{OH})_{2}$ does not precipitate, because $\left[\mathrm{Me}^{2+}\right] \cdot\left[\mathrm{OH}^{-}\right]^{2}<K_{\text {so }}$ $\left(K_{\text {so } \mathrm{Ca}(\mathrm{OH})_{2}}=10^{-5.12}, K_{\text {so } \mathrm{Sr}(\mathrm{OH})_{2} \cdot 8 \mathrm{H}_{2} \mathrm{O}}=10^{-3}\right.$, $\left.K_{\text {so } \mathrm{Ba}(\mathrm{OH})_{2} \cdot 8 \mathrm{H}_{2} \mathrm{O}}=10^{-2.7}\right)$.

The association constants were calculated using the value $a_{\mathrm{Me}^{2+}}$, taking into account only the complexation reaction between the ligand $\mathrm{OH}^{-}$and the $\mathrm{Me}^{2+}\left(\mathrm{Ca}^{2+}\right.$, $\mathrm{Sr}^{2+}$, or $\mathrm{Ba}^{2+}$ ) ion (eq. (23)) [20].

The stability constant $\left(K_{\mathrm{MeOH}^{+}}\right)$is expressed in the following manner:

$$
K_{\mathrm{MeOH}^{+}}=\frac{a_{\mathrm{MeOH}^{+}}}{a_{\mathrm{Me}^{2+}} \cdot a_{\mathrm{OH}^{-}}} .
$$

The association constants of the surface groups of $\mathrm{PC}$ with $\mathrm{OH}^{-}, \mathrm{Cl}^{-}$, and $\mathrm{H}^{+}$, ions $\left(K_{1}=3.351 \cdot 10^{9} \frac{\mathrm{m}^{3}}{\mathrm{~mol}}\right.$, $K_{2}=0.076 \frac{\mathrm{m}^{3}}{\mathrm{~mol}}$, and $K_{3}=717.2 \frac{\mathrm{m}^{3}}{\mathrm{~mol}}$, respectively) were determined previously [6]. Similar calculations for a similar model are also described in detail in [7]. The association constants $K_{1}, K_{2}$, and $K_{3}$ were used to determine the association constants $K_{4}, K_{5}, K_{6}$, and $K_{7}$.

Equation (22) contains more parameters than necessary for constants to be determined. Thus, the association constants can independently determine more than one parameter. Constants determined independently of these parameters give the same or very similar values. The parameters may be used to calculate theoretical points using eq. (21). The surface concentrations of $\mathrm{B}^{+}$and $\mathrm{A}^{-}$are 


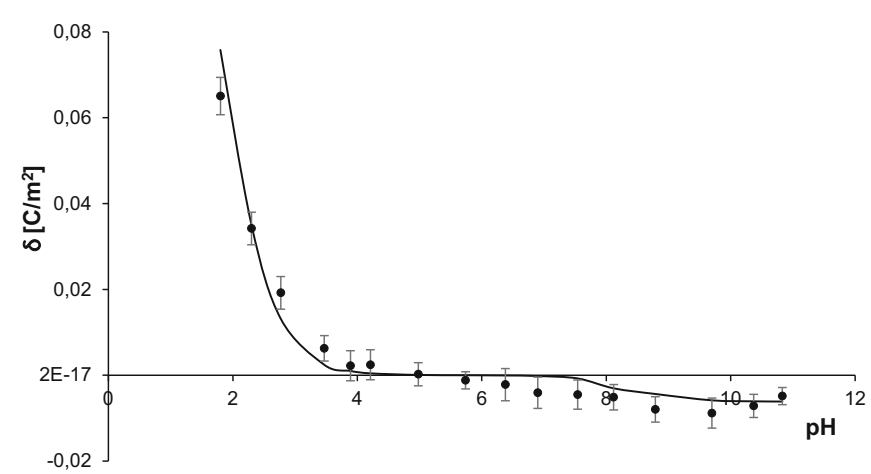

Fig. 1. Membrane surface charge density of the PC liposomal membrane as a function of $p \mathrm{H}$ of the $1 \mathrm{mM} \mathrm{CaCl} \mathrm{Cl}_{2}$ solution (the experimental values are marked by points and the theoretical ones by the line).

evaluated from eqs. (19) and (20), respectively. The concentration of $\mathrm{A}^{-}$is determined from the quadratic equation (eq. (20)), assuming positive values of the solution and rejecting negative ones which do not have physical meaning. The theoretical curves determined in this way are marked on the figures with solid lines.

The degree of coverage of the liposomal surface occupied by $\mathrm{PC}$ with the $\mathrm{H}^{+}, \mathrm{Me}^{2+}, \mathrm{OH}^{-}$, and $\mathrm{Cl}^{-}$ions was determined from the following equation:

$$
\Theta_{x}=\frac{a_{x}}{C_{\mathrm{PC}}}
$$

where $x=\mathrm{A}^{-}, \mathrm{AH}, \mathrm{AMe}^{+}, \mathrm{A}_{2} \mathrm{Me}, \mathrm{AMeOH}, \mathrm{AMeCl}, \mathrm{B}^{+}$, $\mathrm{BOH}, \mathrm{BCl}$.

\section{Results and discussion}

The electrophoretic mobility of PC liposome membranes was measured experimentally at different $p \mathrm{H}$ values of the electrolyte solution $\left(1 \mathrm{mM} \mathrm{CaCl}_{2}, 1 \mathrm{mM} \mathrm{SrCl} \mathrm{Sr}_{2}\right.$, or $1 \mathrm{mM}$ $\mathrm{BaCl}_{2}$ ), and the surface charge density was calculated via eq. (1). The theoretical values of the membrane surface charge density were calculated via the seven-equilibrium mathematical model described in the "Theory" section.

The $p \mathrm{H}$ dependence of the surface charge density of the $\mathrm{PC}$ liposomal membrane in the $\mathrm{MeCl}_{2}$ solution $\left(\mathrm{CaCl}_{2}\right.$, $\mathrm{SrCl}_{2}$, or $\mathrm{BaCl}_{2}$ ) is plotted in figs. 1-3, with the experimental values marked by points and the theoretical values (obtained from eq. (21)) marked by solid lines. The theoretical curves are also shown. Good agreement is achieved between the theoretical and experimental surface charge density values. This confirms the proposed model of the phenomenon.

The association constants of the surface groups of $\mathrm{PC}$ with $\mathrm{H}^{+}, \mathrm{OH}^{-}$, and $\mathrm{Cl}^{-}\left(K_{1}, K_{2}\right.$, and $K_{3}$, respectively $)$ were determined previously [6]. The association constants of the surface groups $-\mathrm{PO}^{(-)} \mathrm{Me}^{(2+)},\left(-\mathrm{PO}^{(-)}\right)_{2} \mathrm{Me}^{(2+)}$, $-\mathrm{PO}^{(-)} \mathrm{Me}^{(2+)} \mathrm{OH}^{(-)}$, and $-\mathrm{PO}^{(-)} \mathrm{Ca}^{(2+)} \mathrm{Cl}^{(-)}\left(K_{4}, K_{5}\right.$, $K_{6}$, and $K_{7}$, respectively) were determined by using eqs. (19), (20), and (22) and are shown in table 2. The

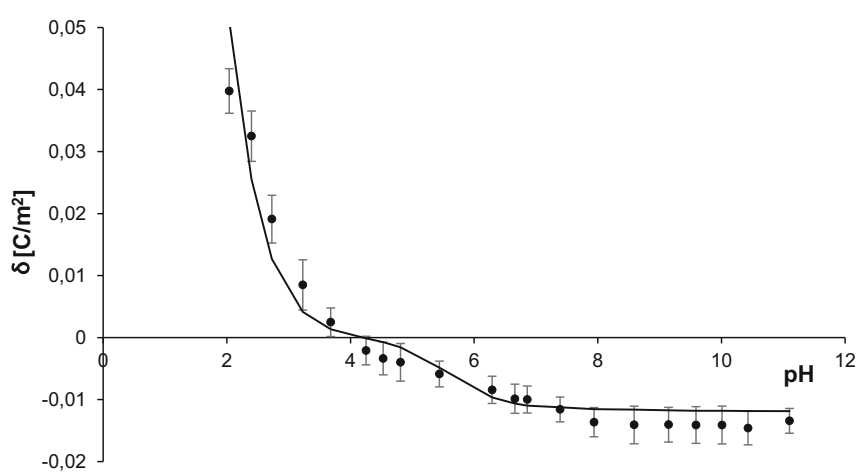

Fig. 2. Membrane surface charge density of the $\mathrm{PC}$ liposomal membrane as a function of $p \mathrm{H}$ of the $1 \mathrm{mM} \mathrm{SrCl}_{2}$ solution (the experimental values are marked by points and the theoretical ones by the line).

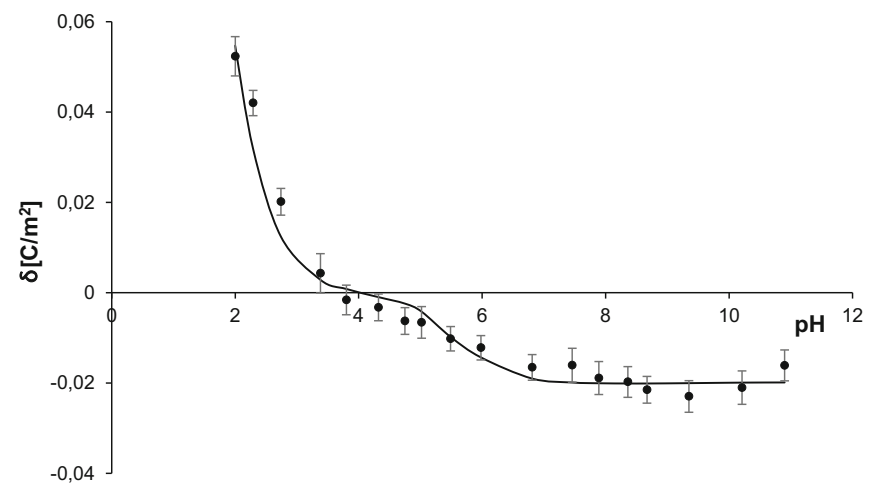

Fig. 3. Membrane surface charge density of the $\mathrm{PC}$ liposomal membrane as a function of $p \mathrm{H}$ of the $1 \mathrm{mM} \mathrm{BaCl}_{2}$ solution (the experimental values are marked by points and the theoretical ones by the line).

largest decrease of negative charge occurred under the influence of $\mathrm{Ca}^{2+}$, and the smallest decrease occurred under the influence of $\mathrm{Ba}^{2+}$ (figs. 1-3). The $-\mathrm{PO}^{(-)}$groups of $\mathrm{PC}$ molecules were stronger when covered by $\mathrm{Ca}^{2+}$ and $\mathrm{CaOH}^{+}$ions compared to when they were covered by $\mathrm{Sr}^{2+}, \mathrm{SrOH}^{+}, \mathrm{Ba}^{2+}$, or $\mathrm{BaOH}^{+}$ions, as evidenced by the fact that the association constants $K_{4}$ and $K_{6}$ for $\mathrm{Ca}^{2+}$ had the highest values $\left(1.24\right.$ and $789.6 \mathrm{~m}^{3} / \mathrm{mol}$, respectively). The $\mathrm{OH}^{-}$-containing ion groups were adsorbed on the membrane surface more strongly than the free metal cations because the association constants of $-\mathrm{PO}^{(-)} \mathrm{Me}^{(2+)} \mathrm{OH}^{(-)}$had higher values than the association constants of $-\mathrm{PO}^{(-)} \mathrm{Me}^{(2+)}$ (table 2).

Figure 4 presents the degree of coverage of the PC membrane surface with ions as a function of the $p \mathrm{H}$ in $1 \mathrm{mM} \mathrm{CaCl}$. We evaluated whether the coverage with $\mathrm{Ca}^{2+}$ and $\mathrm{Cl}^{-}$ions was large enough, in addition to coverage by $\mathrm{H}^{+}$and $\mathrm{OH}^{-}$ions, to affect the $\mathrm{PC}$ membrane surface charge. Adsorption of $\mathrm{Ca}^{2+}$ ions started at $p \mathrm{H}>4.5$, when the amount of $\mathrm{H}^{+}$ions was low; however, it started to decrease at $p \mathrm{H}>9$, when the amount of $\mathrm{OH}^{-}$ions was high. In a strongly basic solution, the degree of coverage of the membrane with $\mathrm{Ca}^{2+}$ ions was almost zero. 
Table 2. The association constants and Gibbs free energy change of the phospholipid functional group with the $\mathrm{Me}^{2+}$, $\mathrm{OH}^{-}, \mathrm{Cl}^{-}$ions $\left(T=25^{\circ} \mathrm{C}\right)$.

\begin{tabular}{|c|c|c|c|}
\hline & $\mathrm{Ca}^{2+}$ & $\mathrm{Sr}^{2+}$ & $\mathrm{Ba}^{2+}$ \\
\hline$K_{4}\left(\frac{\mathrm{m}^{3}}{\mathrm{~mol}}\right)$ & 1.24 & 1.16 & 1.08 \\
\hline$\Delta G_{4}^{0}\left(\frac{\mathrm{kJ}}{\mathrm{mol}}\right)$ & -17.64 & -17.47 & -17.30 \\
\hline$K_{5}\left(10^{-2} \frac{\mathrm{m}^{3}}{\mathrm{~mol}}\right)$ & 4.64 & 3.69 & 1.95 \\
\hline$\Delta G_{5}^{0}\left(\frac{\mathrm{kJ}}{\mathrm{mol}}\right)$ & -9.50 & -8.94 & -7.36 \\
\hline$K_{6}\left(\frac{\mathrm{m}^{3}}{\mathrm{~mol}}\right)$ & 789.6 & 73.8 & 66.4 \\
\hline$\Delta G_{6}^{0}\left(\frac{\mathrm{kJ}}{\mathrm{mol}}\right)$ & -33.63 & -27.76 & -27.50 \\
\hline$K_{7}\left(10^{-4} \frac{\mathrm{m}^{3}}{\mathrm{~mol}}\right)$ & 1.24 & 0.39 & 0.31 \\
\hline$\Delta G_{7}^{0}\left(\frac{\mathrm{kJ}}{\mathrm{mol}}\right)$ & 5.17 & 8.03 & 8.60 \\
\hline
\end{tabular}

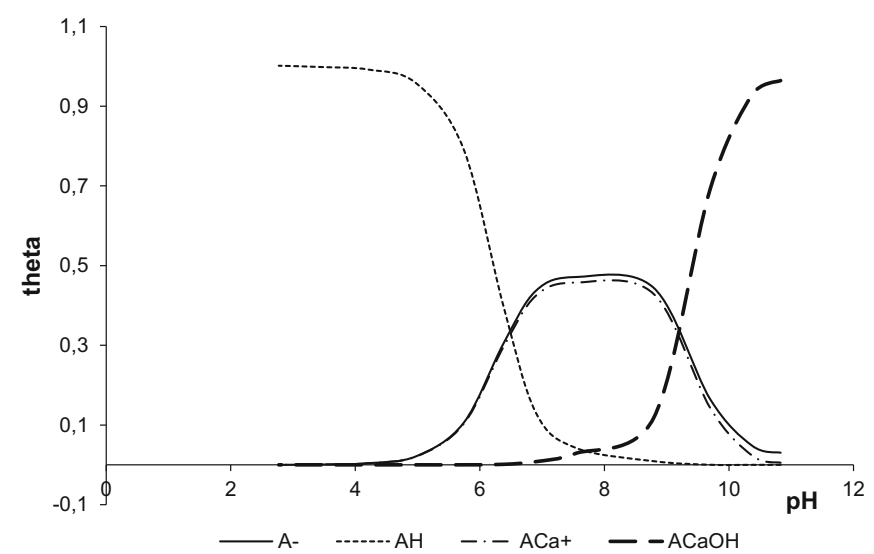

Fig. 4. The degree of coverage of the phosphatidylcholine membrane surface, $\theta$, with the $\mathrm{H}^{+}, \mathrm{Ca}^{2+}, \mathrm{CaOH}^{+}$ions, calculated from eq. (26), as a function of $p \mathrm{H}$ of the $1 \mathrm{mM} \mathrm{CaCl}_{2}$ solution.

Coverage of the membrane surface by $\mathrm{Ca}^{2+}$ ions remained unchanged at around 0.5 in the $p \mathrm{H}$ range of 7-9.

Above $p \mathrm{H} 7, \mathrm{ACaOH}$ groups began to appear on the membrane surface. In a strongly basic solution, the degree of coverage of the membrane with $\mathrm{ACaOH}$ was approximately 1 (i.e., the surface was almost completely covered with these groups). Adsorption of $\mathrm{Cl}^{-}$ions began when the amount of $\mathrm{OH}^{-}$ions started to decrease $(p \mathrm{H}<2.5)$, which was presented in our previous work [6]. In a strongly acidic solution, the degree of coverage of the membrane with $\mathrm{Cl}^{-}$ions reached 0.02 (i.e., the membrane was very poorly covered with $\mathrm{Cl}^{-}$ions).

Figure 5 shows that the adsorption of $\mathrm{Sr}^{2+}$ began at $p \mathrm{H}>4$, reaching a maximum constant value of 0.46 in the $p \mathrm{H}$ range of $7-8.5$. In a strongly basic solution $(p \mathrm{H}>$ 11 ), the degree of coverage of the membrane with $\mathrm{Ca}^{2+}$ ions decreased to almost zero. Above $p \mathrm{H} 7, \mathrm{ASrOH}$ groups began to appear on the membrane surface. In a strongly basic solution, the degree of coverage of the membrane with $\mathrm{ASrOH}$ was almost 0.9 .

The degree of coverage of the PC membrane surface with ions as a function of the $p \mathrm{H}$ in $1 \mathrm{mM} \mathrm{BaCl}_{2}$ is presented in fig. 6. Adsorption of $\mathrm{Ba}^{2+}$ began when the

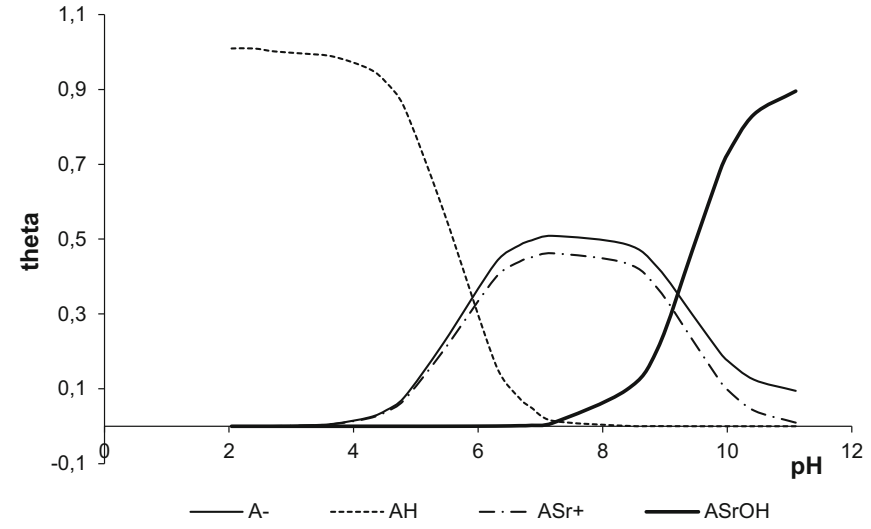

Fig. 5. The degree of coverage of the phosphatidylcholine membrane surface, $\theta$, with the $\mathrm{H}^{+}, \mathrm{Sr}^{2+}, \mathrm{SrOH}^{+}$ions, calculated from eq. (26), as a function of $p \mathrm{H}$ of the $1 \mathrm{mM} \mathrm{SrCl}_{2}$ solution.

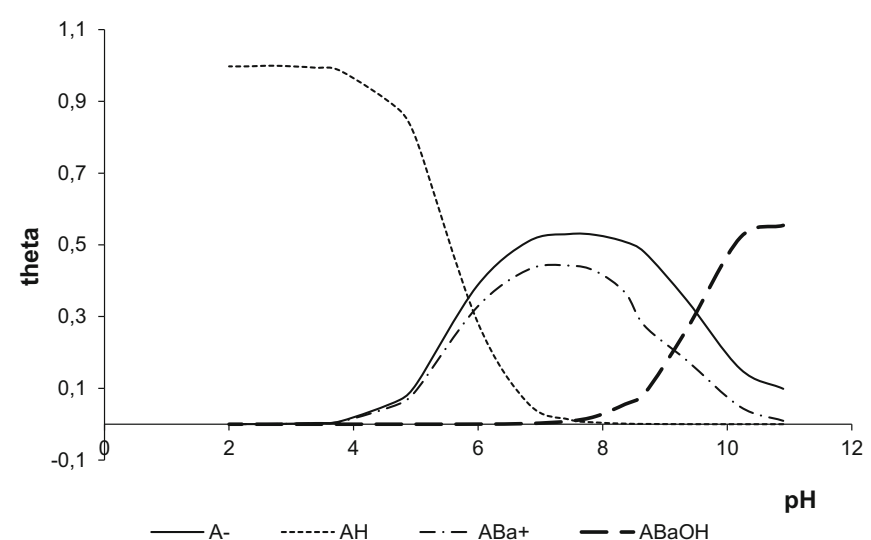

Fig. 6. The degree of coverage of the phosphatidylcholine membrane surface, $\theta$, with the $\mathrm{H}^{+}, \mathrm{Ba}^{2+}, \mathrm{BaOH}^{+}$ions, calculated for from eq. (26), as a function of $p \mathrm{H}$ of the $1 \mathrm{mM}$ $\mathrm{BaCl}_{2}$ solution.

amount of $\mathrm{H}^{+}$ions became low $(p \mathrm{H}>4.5)$, reaching a maximum constant value of 0.42 at $p \mathrm{H} 6.5-8$. Similar results were obtained with $\mathrm{Ca}^{2+}$ and $\mathrm{Sr}^{2+}$ ions. The degree of coverage of the membrane with $\mathrm{Ba}^{2+}$ ions decreased to

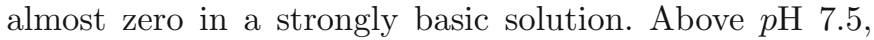
$\mathrm{ABaOH}$ groups began to appear on the membrane surface. In a strongly basic solution, the degree of coverage of the membrane with $\mathrm{ABaOH}$ was almost 0.5.

The system of adsorbed ions is quite complicated. The individual adsorbent systems are competitive with each other. The degree of coverage of the membrane with $\mathrm{A}_{2} \mathrm{Me}$ or $\mathrm{AMeCl}$ was very low $(\sim 0)$; therefore, it is not presented in figs. 4-6. The association constants of the $\left(-\mathrm{PO}^{(-)}\right)_{2} \mathrm{Me}^{(2+)}$ surface groups were about $10^{2}$ times smaller than those of $-\mathrm{PO}^{(-)} \mathrm{Me}^{(2+)}$. Thus, the membrane surface was more complex with $-\mathrm{PO}^{(-)} \mathrm{Me}^{(2+)}$ than with $\left(-\mathrm{PO}^{(-)}\right)_{2} \mathrm{Me}^{(2+)}$. The $\mathrm{A}_{2} \mathrm{Me}$ complex hardly occurs on the surface of the membrane, because it is easier to attach the $\mathrm{OH}^{-}$ion from the solution to the $\mathrm{AMe}^{+}$ group. This may be due to the high value of the association constant associated with the geometric conditioning. 
The association constant values of the surface groups of $-\mathrm{PO}^{(-)} \mathrm{Me}^{(2+)} \mathrm{Cl}^{(-)}$were lower than those of the $-\mathrm{PO}^{(-)} \mathrm{Me}^{(2+)} \mathrm{OH}^{(-)}$and $-\mathrm{PO}^{(-)} \mathrm{Me}^{(2+)}$ groups.

The divalent cation affinities for the $\mathrm{PC}$ liposome membranes went in the order of $\mathrm{Ca}^{2+}>\mathrm{Sr}^{2+}>\mathrm{Ba}^{2+}$, consistently with data in the literature [21]. The majority of research concerns the interaction between liposomal components (i.e., zwitterionic and negatively charged lipids) or between the ions present in the environment and liposomal components $[3,22-28]$. In contrast, only a few reports describe the adsorption of ions in terms of $p \mathrm{H}[3,4,8,29,30]$.

The association constants found in the literature were obtained for solutions characterized by a much richer composition in which other complexes of these ions were also present; therefore, a comparison of these values with ours would not be adequate $[25,26]$.

\section{Conclusion}

This paper describes the influence of divalent ions on the surface charge density of the PC liposomal membrane as a function of $p \mathrm{H}$ through mathematical equations, with experimental confirmation. The following conclusions can be made:

1) The association constant of the $-\mathrm{PO}^{(-)} \mathrm{Ca}^{(2+)}$ group with the PC membrane has the highest value, whereas the association constant of the $-\mathrm{PO}^{(-)} \mathrm{Ba}^{(2+)}$ group has the lowest value. Therefore, the membrane surface adsorbs the largest amount of $\mathrm{Ca}^{2+}$ ions and the least amount of $\mathrm{Ba}^{2+}$ ions.

2) The $\mathrm{OH}^{-}$-containing ion groups are adsorbed on the membrane surface more strongly than the free metal cations because the association constants of $\mathrm{PO}^{(-)} \mathrm{Me}^{(2+)} \mathrm{OH}^{(-)}$have higher values than the association constants of $-\mathrm{PO}^{(-)} \mathrm{Me}^{(2+)}$.

3) Association constants of the $\left(-\mathrm{PO}^{(-)}\right)_{2} \mathrm{Me}^{(2+)}$ surface groups with the PC membrane are about $10^{2}$ times smaller than association constants of the $\mathrm{PO}^{(-)} \mathrm{Me}^{(2+)}$ groups. Thus, the membrane surface is more complex with $-\mathrm{PO}^{(-)} \mathrm{Me}^{(2+)}$ than with the ($\left.\mathrm{PO}^{(-)}\right)_{2} \mathrm{Me}^{(2+)}$ group.

4) Association constants of the $-\mathrm{PO}^{(-)} \mathrm{Me}^{(2+)} \mathrm{Cl}^{(-)}$surface groups with the PC membrane are considerably lower than association constants of the $\mathrm{PO}^{(-)} \mathrm{Me}^{(2+)} \mathrm{OH}^{(-)}$and $-\mathrm{PO}^{(-)} \mathrm{Me}^{(2+)}$ groups.

5) The validity of the proposed models is demonstrated by the good agreement of the experimental and theoretical charge variation curves of the PC liposomal membranes.

This publication has received financial support from the Polish Ministry of Science and Higher Education under subsidy for maintaining the research potential of the Faculty of Biological and Chemical, University of Bialystok. Zetasizer Nano ZS was funded by the European Funds for Regional Development and the National Funds of Ministry of Science and Higher Education, as part of the Operational Programme Development of Eastern Poland 2007-2013, project: POPW.01.03.0020-044/11.
Open Access This is an open access article distributed under the terms of the Creative Commons Attribution License (http://creativecommons.org/licenses/by/4.0), which permits unrestricted use, distribution, and reproduction in any medium, provided the original work is properly cited.

\section{References}

1. P.R. Cullis, M.J. Hope, M.B. Bally, T.D. Madden, L.D. Mayer, D.B. Fenske, Biochim. Biophys. Acta 1331, 187 (1997).

2. C. Kent, Biochim. Biophys. Acta 1733, 53 (2005).

3. S. McLaughlin, N. Mulrine, T. Gresalfi, G. Vaio, A. McLaughlin, J. Gen. Physiol. 77, 445 (1981).

4. P.M. Mcdonald, J. Seeling, Biochemistry 27, 6769 (1988).

5. B. Klasczyk, V. Knecht, R. Lipowsky, R. Dimova, Langmuir 26, 18951 (2010).

6. I. Dobrzyńska, J. Kotyńska, Z. Figaszewski, Chem. Anal. 52, 931 (2007)

7. I. Dobrzyńska, J. Kotyńska, B. Szachowicz-Petelska, Z. Figaszewski, Soft Mater. 15, 113 (2017).

8. J. Kotyńska, I. Dobrzyńska, Z.A. Figaszewski, Eur. Biophys. J. 46, 149 (2017).

9. M. Rappolt, K. Pressl, G. Pabst, P. Laggner, Biochim. Biophys. Acta Biomembr. 1372, 389 (1998).

10. S. Garcia-Manyes, G. Oncins, F. Sanz, Biophys. J. 89, 1812 (2005).

11. J. Kotyńska, I. Dobrzyńska, Z.A. Figaszewski, J. Bioenerg. Biomembr. 40, 637 (2008).

12. H.C. Lee, R. Aarhus, T.F. Walseth, Science 261, 352 (1993).

13. S.L. Mironov, M.U. Juri, Neurosci. Lett. 112, 184 (1990).

14. H.T. McMahon, D.G. Nicholls, J. Neurochem. 61, 110 (1993).

15. E.A. Nalefski, J.J. Falke, Protein Sci. 5, 2375 (1996).

16. W.G. Regehr, M.R. Carey, A.R. Best, Neuron 63, 154 (2009).

17. T.S. Sihra, D. Piomelli, R.A. Nichols, J. Neurochem. 61, 1220 (1993).

18. M. Verhage, J.J.H. Hens, P.N. De Graan, F. Boomsma, V.M. Wiegant, F.H. Lopes da Silva, W.H. Gispen, W.E. Ghijsen, Eur. J. Pharmacol. 291, 397 (1995).

19. A.E. Alexander, P. Johnson, Colloid Sciences (Clarendon Press, Oxford, 1949).

20. J. Inczedy, Analytical Applications of Complex Equilibrium (Ellis Horwood, 1976).

21. A. McLaughlin, C. Grathwohl, S. McLaughlin, Biochim. Biophys. Acta 513, 338 (1978).

22. S.A. Pandit, D. Bostick, M.L. Berkowitz, Biophys. J. 84, 743 (2003).

23. H. Binder, O. Zschörnig, Chem. Phys. Lipids 115, 39 (2002).

24. S. Carnie, S. McLaughlin, Biophys. J. 44, 325 (1983).

25. J.A. Cohen, M. Cohen, Biophys. J. 36, 623 (1981).

26. S.A. Tatulian, Eur. J. Biochem. 170, 413 (1987).

27. K. Satoh, Biochim. Biophys. Acta 1239, 239 (1995).

28. N. Kučerka, E. Dushanov, K.T. Kholmurodov, J. Katsaras, D. Uhríková, J. Phys.: Conf. Ser. 849, 12008 (2017).

29. M. Mullet, P. Fievet, J.P. Reggiani, J. Pagetti, J. Membr. Sci. 123, 255 (1997).

30. F. Roosen-Runge, B.S. Heck, F. Zhang, O. Kohlbacker, F. Schreiber, J. Phys. Chem. B 117, 5777 (2013). 